ZOOLOGIA 31 (4): 405-407, August, 2014

http://dx.doi.org/10.1590/S1984-46702014000400013

\title{
Description of the male of Yabisi guaba (Araneae: Eresoidea: Hersiliidae)
}

\author{
Cristina A. Rheims ${ }^{1}$, Ingi Agnarsson² \& Giraldo Alayón Garcia ${ }^{3}$
}

\author{
${ }^{1}$ Laboratório Especial de Coleções Zoológicas, Instituto Butantan. Avenida Vital Brasil 1500, 05503-900 São Paulo, SP, Brazil. \\ E-mail: carheims@gmail.com \\ ${ }^{2}$ Department of Biology, University of Vermont. 109 Carrigan Drive, Burlington, Vermont 05405 USA. \\ E-mail: iagnarsson@gmail.com \\ ${ }^{3}$ Museo Nacional de Historia Natural, Obispo 61, Ciudad de La Habana, C.P. 10100, Cuba E-mail: moffly@infomed.sld.cu
}

\begin{abstract}
Hersiliidae is a relatively small spider family that is easily distinguished by the very long posterior lateral spinnerets. It is distributed worldwide and, although quite diverse in other zoogeographical regions, is represented by only 11 species in the Neotropics. Hersiliidae was recently revised and of the 11 species, three are known solely from one sex. Yabisi Rheims \& Brescovit, 2004 includes only two species, one of which is known solely from the female. The genus is extremely rare and both species are known from only a few specimens. In this paper, the male of Yabisi guaba Rheims \& Brescovit, 2004 is described and illustrated and an extended diagnosis is given for the genus. The male of this species is distinguished from its congener by the palps, with laminar embolus having the same width throughout its length and median apophysis narrow and distally rounded.
\end{abstract}

KEY WORDS. Dominican Republic; Neotropical region; spiders; taxonomy.

Hersiliidae belongs to the enigmatic and understudied Eresoidea, a taxon that is considered important for understanding the phylogeny of Entelegynae spiders (Coddington \& LeVI 1991, Agnarsson et al. 2013). It is easily distinguished from all other araneomorph families in having very long posterior lateral spinnerets. These spinnerets are also elongated in the related Oecobiidae but to a much lesser extent. In both families, these structures are used in a characteristic hunting behavior in which the spider quickly rotates around the prey while fixing it to the substrate with silk (LAWRENCE 1964, EвERHARD 1967, SHEAR 1968). Hersiliidae is a relatively small family with 179 species distributed in 15 genera (Platnick 2014). Although quite diverse in most zoogeographical regions, few species occur in the New World. In a revision of the Neotropical and Nearctic species, RheIms \& BRescovit (2004) included only eleven species in four genera. These are Iviraiva Rheims \& Brescovit, 2004, with two species, Neotama Baehr \& Baehr, 1993, with four, Yabisi Rheims \& Brescovit, 2004, with two and Ypypuera Rheims \& Brescovit, 2004, with three (Platnick 2014). Despite the large quantities of material examined by Rherms \& BRescovit (2004), three species, Neotama forcipata (F.O.P.-Cambridge, 1902), Ypypuera esquisita Rheims \& Brescovit, 2004 and Yabisi guaba Rheims \& Brescovit, 2004, remain known solely from one sex. Yabisi was proposed by RHeIMs \& BRESCOVIT (2004) to include the type species Tama habanensis Franganillo, 1936 and a new species, Yabisi guaba Rheims \& Brescovit, 2004, from the Dominican Republic. The genus is extremely rare and both species are known from a few specimens. They are usually col- lected from the bark of large trees in the edges of forests (G. Alayón Garcia pers. obs.). In this paper, we describe the male of $Y$. guaba and provide an extended diagnosis for the genus. The material examined is deposited in the National Museum of Natural History, Washington. D.C., USA (NMNH, curator: J.A. Coddington).

\section{TAXONOMY}

\section{Yabisi Rheims \& Brescovit 2004}

Yabisi Rheims \& Brescovit, 2004: 232 (Type species: Tama habanensis Franganillo 1936, by original designation). Platnick, 2014.

Diagnosis. Species of Yabisi Rheims \& Brescovit, 2004 are distinguished from those of the other New World genera by the unmodified metatarsi I, II and IV (RHEIMs \& BRESCOVIT 2004: fig. 27). Males are further distinguished by the palps with embolus short and twisted and median apophysis rounded at tip, both inserted apically in the tegulum (Figs 3-5, Rheims \& BRESCOVIT 2004: figs 117-118); females are further distinguished by having the epigyne with lateral lobes without projections, median septum large, subsquared or slightly triangular (RHeIms \& BREsCovit 2004: figs 119, 124) and kidney shaped spermathecae (RHeIms \& BRESCOVIT 2004: figs 120, 125).

Species composition. Yabisi habanensis (Franganillo, 1936); Yabisi guaba Rheims, 2004.

Species distribution. Southern United States, Cuba and Dominican Republic. 

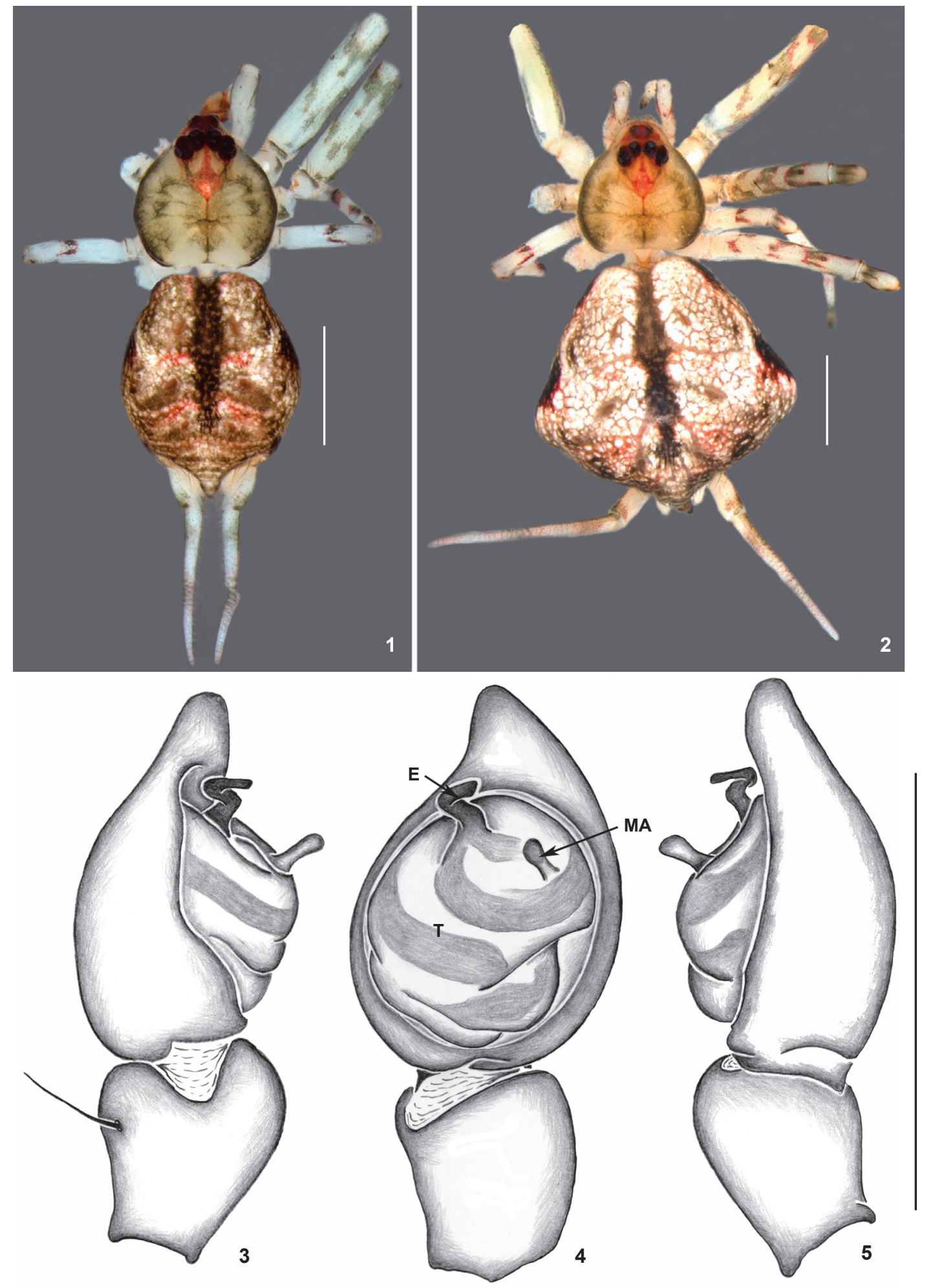

Figures 1-5. Yabisi guaba. (1-2) Habitus, dorsal view: (1) male; (2) female. (3-5) Male, left palp: (3) prolateral view; (4) ventral view; (5) retrolateral view. (E) Embolus, (MA) median apophysis, $(T)$ tegulum. Scale bars: 1-2 $=1 \mathrm{~mm}, 3-5=0.5 \mathrm{~mm}$. 


\section{Yabisi guaba Rheims \& Brescovit, 2004 Figs 1-5}

Yabisi guaba Rheims \& Brescovit, 2004: 234, figs 121-125 (Female holotype from $4 \mathrm{~km} \mathrm{~N}$ of Oviedo, Pedernales Province, Dominican Republic, 28 November - 4 December 1991, Masner \& Peck leg., deposited in AMNH). Platnick, 2014.

Additional material examined. Dominican Republic, Monte Cristi Province: forest near Villa Elisa (19.89N-71.65W), 1 male, 1 female, 23 June 2012, Carbio group leg. (NMNH).

Diagnosis. Males of Yabisi guaba Rheims \& Brescovit, 2004 are distinguished from those of Yabisi habanensis Franganillo, 1936 by the palps, with laminar embolus having the same width throughout its length and median apophysis narrow and distally rounded (Figs 3-5). Females are distinguished by the epigynes with rectangular median septum and copulation ducts simple, with no loops (Rheims \& Brescovit 2004: figs 124-125).

Description. Male (NMNH): prosoma (Fig. 1) yellowish cream; cephalic region with median, diamond shaped, reddish mark and two paramedian moss green stripes extending from PME to posterior margin of cephalic region; eye area black, reddish laterally between AME and PLE; thoracic region with moss green margins and moss green marks between thoracic striae; fovea brown with faint moss green mark around it; clypeus moss green; chelicerae yellowish cream with moss green mark at base; legs and pedipalps yellowish cream with dorsal irregular moss green bands; sternum cream with green margins and faint large greenish mark at center; endites cream; labium greenish cream. Opisthosoma (Fig. 1) cream colored. Dorsally variegated moss green and white with dark green heart mark and three pairs of oval, pale brown muscular impressions, the posterior smallest. Ventrally with white marks laterally, epiandrium region moss green and with faint V-shaped pale brown mark medially. Spinneterts almost as long as abdomen, yellowish cream with dorsal moss green bands (Fig. 1). Total length 2.7. Prosoma: 1.2 long, 1.1 wide. Cephalic region: 0.3 high. Opisthosoma: 1.8 long, 1.4 wide. Eyes: diameters: AME 0.12, ALE 0.08, PME 0.11, PLE 0.10. Clypeus height: 0.08 to AME, 0.20 to ALE. Chelicerae: cheliceral groove with three promarginal teeth and four retromarginal denticles. Legs: I: total 7.7 (femur 2.4, patella 0.5, tibia 1.9, metatarsus 2.5, tarsus 0.4); II: (2.1, 0.5, rest of leg absent); III: $2.5(0.8,0.3,0.5,0.5,0.4)$; IV: $6.2(1.7,0.4,1.5,2.2,0.4)$. Palp: tibia as long as cymbium length, with one dorsal-prolateral slender spine; cymbium with large round alveolus, no scopula or distinctive setae; tegulum rounded with retrolateral, strong indentation; median apophysis long and slender, rounded at tip, arising from apical-retrolateral position on tegulum; embolus laminar, twisted retrolaterally and arising from apical position on tegulum (Figs 3-5).

Female. See Rheims \& Brescovit (2004: 234), figs 124-125 (Fig. 2).

Distribution. Known solely from the Dominican Republic.

\section{ACKNOWLEDGEMENTS}

This study was supported by NSF DEB-1314749, and DEB1050187-1050253 (to IA and Greta Binford), the "Fundação de Amparo à Pesquisa do Estado de São Paulo" (FAPESP \#2011/ 18694-3, to CAR), and a grant from the Smithsonian Institution 2013 SI Barcode Network to Jonathan Coddington and IA.

\section{LITERATURE CITED}

Agnarsson, I.; J.A. Coddington \& M. Kuntner. 2013. Systematics - progress in the study of spider diversity and evolution, p. 58-111. In: D. Penney (Ed.). Spider Research in the 21st Century: trends and perspectives. Manchester, Siri Scientific Press, 320p.

Coddington, J.A. \& H.W. Levi. 1991. Systematics and evolution of spiders (Araneae). Annual Review of Ecology and Systematics 22: 565-592. doi: 10.1146/annurev.es.22.110191.003025

EвеRHaRd, W.G. 1967. Attack behavior of digueid spiders and the origin of prey wrapping in spiders. Psyche 74: 173-181.

Lawrence, R.F. 1964. A conspectus of South African spiders. Department of Agricultural Technical Services. South Africa. Science Bulletin 369: 1-64.

Platnick, N.I. 2014. The world spider catalog, version 14.5. American Museum of Natural History, available online at http://research.amnh.org/entomology/spiders/catalog/ index.html [Accessed: 03/VI/2014]. doi: 10.5531/db.iz.0001

Rherms, C.A. \& A.D. Brescovit. 2004. Revision and cladistic analysis of the spider family Hersiliidae (Arachnida, Araneae) with emphasis on Neotropical and Nearctic species. Insect Systematics and Evolution 35: 189-239. doi: 10.1163/ 187631204788912355.

SHEAR, W.A. 1968. Introduction, p. 1-7. In: W.A. SHEAR (Ed.) Spiders. Webs, behavior and evolution. Stanford, Stanford University Press, 492p.

Submitted: 27.I.2014; Accepted: 06.VII.2014.

Editorial responsibility: Antonio D. Brescovit 